IDEA - Studia nad strukturą i rozwojem pojęć filozoficznych $\mathrm{XXIX/2}$ Białystok 2017

\author{
Felix Ayemere Airoboman \\ (Benin, Nigeria)

\section{AN INQUIRY INTO THE METAPHYSICAL CAUSES OF DEATH IN ESAN CULTURE}

\title{
Introduction
}

Esan is one of the three major ethnic groups in Edo state, Nigeria. The word Esan refers to the person, the people, the culture and geography of Esanland. Fundamentally, the concept of death is a metaphysical phenomenon among Esan people. Death is an event which must occur in one's life without waiver. Its place and time of occurrence and its next victim cannot be predicted with absolute certainty. It is a game which does not admit any replay. The people of Esan, like most other human beings, have the insatiable instinct of survival. This is why they are perplexed with the mystery and inevitability of death and its final victory over material existence. They asked questions about birth, life and death. For the Esan, the ordinary, empirical answers to the why of death, just like the answers to the why of birth and the why of life do not satisfy any ontological yearning. But ontological answers to these questions contravene ordinary experience. This is because attempted answers are maximally anchored on non-empirical realities. Therefore, answers to these questions in whichever way open Pandora's Box.

Regardless of these seeming irresolvable puzzles, it is philosophically wise, potent and worthwhile to attempt some intellectual muscle flexing, though not to completely eliminate the puzzles, but at least to serve as palliative to the minds with unquenchable thirst for knowledge about these issues at hand. To do this, this article attempts a critical discussion of Esan view of death and their 
understanding of the causes of death which include witchcraft, divinities, God, spirits, diabolic persons, and evil consequences of the acts of the victim or of his relatives. Although the Esan people's beliefs about the causes of death are subjected to epistemological and logical infelicities, these beliefs influence their disposition and moral practice toward both the living and the dead in their daily living. This study employs the expository and comparative methods, as well as the method of critical analysis. The study is justified because a proper understanding of the matter in focus can inform people's attitude when death occur. This would enable people to accept death as a natural phenomenon, erase suspicion that can generate acrimony among people whenever death occur and the indictment, death, killing, and stigmatization of innocent people whenever death occurs.

There are variations in the awareness of death from person to person, epoch to epoch, time to time and culture to culture (Olson (2006, 651). These variations are reflected in the general explanation of death, including the meaning, causes, fear, implication of, and attitude to death and the fate of the dead. In the discipline of philosophy, very little attention has been given to these questions. Attention to these issues is necessary in philosophy since maximally, philosophy is concerned with human condition and death is a part of this human condition.

\section{Understanding the Concept of Death in Esan}

Death as a phenomenon is an irreversible cessation of life. In Esan it "is regarded as a transition from one state of existence to another. It is the last of the rites of passage that a person has to go through on earth (others being birth, puberty, marriage)" (Alli, 2011: 25-26). Deaths are believed to be caused. This causality is a constitutive part of Esan ontology. Esan people believe that at any stage an individual dies, and even for empirical misfortunes, they are caused by some agents for some purposes. This is why death is not only conceived as bad, it also suggests that one ought not to die. But ironically, the Esan people also believe that death is inevitable. Death is an unavoidable experience that awaits everyone. It is therefore onerous for everyone to live a good life here and await the next. Although it is an unavoidable phenomenon, the peoples' belief and attitudes towards death epitomizes their willingness to continue life ad infinitum. 
This desirability reflects the belief that life is good despite its challenges and, death is bad despite its promises.

Partly because of the conception that life is good and death is bad, the Esan people mourn for the dead grievously and strenuously too. Mourning the dead is premissed not on the cessation or forfeiture of benefits derived from the deceased, but on feelings. The Esan empathize the dead. His or her absence in the scheme of things, the vacuum which his or her demise creates, his uniqueness and irreplaceability make his or her death deeply felt. People also weep for the dead because of human frailty, fear of the unknown and the agony and groaning exhibited by the dying, among others. When they see people die in agony and groaning, they fear the pain of death since that also awaits them. When death comes, there is no excuse, no appeal and no sympathy. Despite all the beliefs which Esan people have about death and the hereafter, epistemologically speaking, no one really knows exactly what lies beyond the physical universe. Indeed, philosophically speaking, for the people, death is a mystery. Why death?

\section{Death as Mystery}

The Esan question of the "why of death" cannot be satisfactorily answered. Attempted answers are maximally anchored on fables. Where they are existential, they cannot satisfy any ontological yearning. The attempt to satisfy this yearning requires answers to the why of life and the why of birth? These, like the first question are also bereft of any satisfactory answer. It may therefore be the case that any attempts to unravel the mysteries of birth, life and death with absolute certainty are futile and absurd, or, it may be that human capacity for knowledge and wisdom is tainted with finitude and is thus incapacitated in unraveling these meanings or answers to these why questions.

The wise and the foolish, rich and poor, king and slave, good and evil have death as a common fate awaiting them. The Boethius question: (Boethius, 1969) why do good people suffer and why do evil men flourish? is preeminent in Esan belief pertaining death. The wise, the good, the strong and the productive may die young and in crises too, while the foolish, evil, weak and counterproductive may die old and peacefully. This is also a mystery. This mystery is couched as: Omon non men bbu unun ise eman. This literarily means a sweet soup is 
never sufficient for pounded yam. The underlying meaning is that what is beneficial does not last. The question again is why death? What causes death?

\section{Natural Causes of Death}

Although the focus of this essay is on the metaphysical causes of death, it seems necessary to consider generally, but briefly, death as a natural phenomenon before engaging in a detailed analysis of Esan traditional understanding of the causes of death. Is death a natural phenomenon? Or can death be natural? This question is relevant because some individuals and some cultures attribute death to some non-natural, metaphysical and religious agencies such as gods or demons, sin or ancestors. For example, Christians see death as punishment for the sins of Adam. The reluctance to explain death in terms of natural causes intersects with the reluctance to explain life itself in natural fashion. This is why the religious or metaphysical perspectives that give rise to non-naturalistic interpretations of life tend also to occasion non-naturalistic interpretations of death (Olson (1967, 2006, 651).

Globally, many people die every year. From an orthodox worldview, death often results from advanced age, illness or accident. Specific causes of death include: heart disease, stroke, blood vessel blockages, respiratory infections, lung disease, diarrhoea, premature births, stillbirths, neonatal deaths, tuberculosis, homicide, suicide, cancer, HIV/AIDS and Motor vehicle crashes (End of Life Care: An Ethical Overview, 2005: 5-6; World Health Organization, 1999). Death can also result from felling from trees, animal attack, drowning (Okojie, 1994 128-132), malaria attack, domestic accident, plain crash, accidental gun discharges, war, clashes, ritual killings, executions, manslaughter, murder, collapsing toilets, and so on.

\section{The Metaphysical Causes of Death}

The analyses of the metaphysical sources of death will constitute the focal point of this session. Although, there are some physical or accidental sources of death resulting from natural causes as outlined above, the real Esan traditional understanding and explanation of the causes of death deviates from them. Even 
when death results from such natural causes, such causes are believed to have ontological underpinnings, that is, such occurrences are always attributed to some non-natural causes. This is because among the people, the belief that there is nothing without an underlying cause has a firm root. This is reflected in the Esan saying that emilin ribho otole, that is, there is something underneath. It is only such ontological explanations that remain meaningful and satisfactory among the people. For example, even when death results from two fighting or deliberate shooting, it is believed that the killer's sense of true reason was distorted or marred to commit such crime, or that his victim was already killed but was only tele-guided for perfection in physical manifestation in the hands of the assumed killer. This is why the Esan would say either: eba lulu non - it is what has been done, or oiyiaboabo - it is not ordinary. The relevance of such belief is that it makes people to have aversion for physical fight to ensure that a person already killed does not have his predicament fulfilled in their own hand. But when this happens, the Esan would say oikayukhe - he was already dead.

Ontologically, deaths arise from different sources, which among others include malevolent and benevolent agents or beings such as:

Witches and Wizards: Witchcraft or wizardry is a concrete phenomenon in Esan discursive universe. Witches and wizards are believed to strategize and operate mysteriously at night in coven where they convene, make decision and perfect their plans, the consequences of which manifests in concrete reality. They are also believed to cause some deaths through the use of evil magic. They prey on human beings for meal or kill them to thwart either their shining or foreseen exemplary destiny, or as a revenge or punishment to their parents, siblings or other relatives, or on account of the victim due to malice. They can also kill people to elevate their status in their realm. The belief in witchcraft and their evil machinations is not limited to Esan people; it is a pervasive belief in Africa and beyond. While writing about Africa, Orubu submits that: "It is believed that witches and wizards can "contribute" fathers, mothers, brothers, and sisters to the coven feasts as demanded. It has been... (speculated - mine) that for coven members to get promoted in the hierarchy, they must, as a rule "contribute" a soul for the witch festival... ...Thus, when a person dies, no matter how old he may be, it is believed that a witch or wizard is responsible" (Orubu, 2001: 155).

Diabolic Persons: The existence of diabolic persons tends to be a characteristic phenomenon of almost all existing community in Esan. They are usually 
very negligible in number, and are usually found among the male folks. They are in most cases retched but dreaded in the community. The source of their power remains a mystery. Diabolic persons can mysteriously cause death of both innocent people and those whom they believe trespass their boundary. They may also be hired by those who do not have the power to do so for the same purposes. They are malevolent like witches and wizards. Apart from causing death, witches, wizards and diabolic persons can inflict pains and injuries on their victims and swop or overturn their destinies. While some of these effects can be counteracted, some cannot. They attack their victims with magic, juju and through manipulations of nature. Just like the Esan, the Yoruba and Ibibio peoples of Nigeria, among others, believe that magic powers can be used to harm an individual and also to cause his death. Magic manipulations are powerful and potent, and are often procured and used by medicine men to achieve evil effects. "Magical preparations may be placed on the door steps of an intended victim. Similarly, such preparations may be sprayed on his or her garments to achieve the desired results". They may also be spread on the footpath of the intended victim or spread on air and specifically teleguided to him for intended purpose. "It is also believed that dogs, snakes, and rats may be sent to bite and to inflict death on a person. Even lightening may be sent to strike down an enemy" (Orubu, 2001: 155). Other measures can be adopted. In any case, some rituals are performed so that the deceased can avenge his death.

Evil Consequences: Death may also result from the evil deed(s) of the individual to restore the disharmony which his sinful act(s) or those of his parents or other relative(s) distort in the ontological balance in the community or elsewhere. Such sinful acts include adultery, incest, murder, contempt of deities and some other acts considered sacrilegious and desecrating in the community. If death is considered to result from the evil act(s) of the deceased, the Esan people would say ebo lulu gbo ole, or ole tobole gbe egbole. These respectively mean, it is what he did that killed him or he killed himself. Death may also result from the consequences of ontological evil of the entire community.

Deities: Deities are believed to be responsible for some deaths. Similar to the point just examined, the death of an individual may be due to the vengeance of deities due to either the wrongs of the individual, his family or his community. When such death does not result on account of the sin of the individual, an appeasement is made to the deities for forgiveness to prevent other occurrences. Even when it results on his account, appeasement can also be made to waive off 
the consequences for him in the hereafter and to insure other member of the family or community as the case may be, from committing such crime or incurring such wrath. The duty of the deities is multi-directional. It is not only to enforce vengeance; they also protect. Just like in most African communities, the deities are believed

to protect all the people in the locality. It also takes vengeance on evil doers for offences and crimes committed in secret. People may swear by the deity. In fact, individuals may be tried before the deities for various offences. It may thus be invoked to find out the guilty party. It is believed that the local deities do their work by causing the death of offenders (Orubu, 2001:156).

Such deities in Esan, among the litany of deities include ogun, ukbuekbie, omonruare, obiemen, onobi, amese, onokun, illa, oba, omobo, otobo, iyan-oto and edion. When offence is detected before death, appeasement are made; and when accepted the deity concerned may relent in anger and abort vengeance. Whether in Esan or elsewhere, some deities are believed to be more lenient or more temperamental than others.

The justices of deities can sometimes be perverted or manipulated to reflect public expectation. This is common with extra ordinary means of arbitration and vindication where ordinary human knowledge is defective such as indictment of witchcraft or wizardry, diabolic acts, blatant denial in the ordinary judicial system, and so on. Such cases are usually referred to and tried by some native doctors, priests of sasswood, osunene, alamonka, itan, shrines, and so on, all of which can be manipulated and when not manipulated has no guarantee for true justice. So while the guilty can be acquitted, the innocent can be penalized with capital or near capital punishment. Few of these measures and their after effects will be discussed here. This will be illustrated with itan, sasswood and shrine. Essentially itan is a trial of endurance; and in most cases the result depends upon the vagaries of the itan priest. "If he himself suspected the accused or if he knew public opinion was heavily against the man, or if the onojie was interested in the man's guilt, the result was definite - guilty, would be the verdict!" (Okojie, 1994: 100). Another method is to choose blindly between two alternative symbols of acquittal and guilt. Whichever he chooses is his portion. For the ordinary people this method is definitive of reality; but in reality, it is sheer luck. 
This manipulation of the justices of the deities can also be illustrated with the use of decoction from sasswood. This method is known as the sasswood trial (Okojie, 1994: 101). This trial depended again on more or less upon public thought and feeling towards the accused. In some unfortunate cases where the feeling of antipathy is so strong for the victim and the public desired immediate death, the trial is over-enthusiastic and queer. From the sasswood centre the quantity of decoction from the bark of the sasswood given to the suspect to drink vary depending on the perception which they have on the suspect to reflect their anticipated result. Here an innocent person can be declared guilty and thus punished and even with death or torture to death while a guilty person can be vindicated. Although these practices are not common in Esan, they are not absent.

Comparatively, there was the prevalent manipulation of the justices of deities by malicious priests for pecuniary gains in Igboland. Igbo is another culture in Nigeria. The attainables in the shrine of Arocbuku oracle in Igboland popularly nicknamed the long juju by the British (because it pointed vertically to heaven) are vivid and typical examples of perversion of justice by humans in the name of deities (Webster and Boahen with Idowu, 1967: 185-186; Lucas, 1970: 88-89; Osae and Odunsi, 1973: 98). Here it was dispensation, not of justice, but of injustice. When cases are brought before this shrine, the priests do accept bribe from offenders to distort justice. After accepting bribe from the guilty person, the innocent person is led through an underground tunnel from the shrine to the coast to be sold as slave. Daron Acemoglu and James Robinson explain how the Arochukwu oracle as a religious institution became perverted by the desire to capture and sell slaves. They write that

[t]he oracle was widely believed to speak for a prominent deity in the region respected by the major local ethnic groups, the Ijaw, the Ibibio, and the Igbo. The oracle was approached to settle disputes and adjudicate on disagreements. Plaintiffs who traveled to Arochukwu to face the oracle had to descend from the town into a gorge of the Cross River, where the oracle was housed in a tall cave, the front of which was lined with human skulls. The priests of the oracle, in league with the Aro slavers and merchants, would dispense the decision of the oracle. Often this involved people being "swallowed" by the oracle, which actually meant that once they had passed through the cave, they were lead away down the Cross River and to the waiting ships of the Europeans (Acemoglu and Robinson, 2013: 253, 254). 
This knowledge was not in public space. Then the priests slaughter a cock and sprinkle the blood on a white cloth to show the relatives of the actual innocent person that he or she was the offender and for that reason the gods has taken his or her blood, that is, has killed him or her. This nefarious activity was discovered when slave trade was abolished. Those who were purportedly claimed to be killed by the gods returned home to narrate their experiences. The lining of the front of the shrine with human skulls suggests that these priests have been killing innocent persons in the pretext of dispensation of justice by the gods before they devised the above described heinous mean as an additional source of lucrative business in the shrine.

The Arochuku oracle was no doubt the most powerful oracular cult and the most dreadful institution in Igboland and its environs. It is believed to have the ability to identify wizards, witches and poisoners, among other powers (Basden, 49-52; Lucas, 1970: 88). T.A. Osae and A.T.O Odunsi express their view this way: The people of Aro who were deeply feared because of the oracle manipulated the scenario to enhance their economic powers. They

lured and sold into slavery unwary persons who came to consult the oracle. More often than not the Aro themselves would create situations which necessitated consultation of the oracle. Suspects who were hurried to the oracle to have their innocence or guilt established would mysteriously disappear. The Aro also used the oracle as a means of blackmailing wealthy persons and dispossessing them of their wealth (Osae and Odunsi, 1973: 98).

It is for the gruesome elements contained in the cult that the government suppressed it. In fact, a British expedition was eventually launched to attack the shrine in 1902. This depicts that the supposed justices of the gods may sometimes be reflections of the whims and caprices of the priests of such gods just as the acclaimed, supposed temperaments of the gods are sometimes reflections of the actual temperaments of the priests of such gods.

Spirits: Spirits of the dead are also believed to cause some deaths. Their influence is mostly limited to the family they departed from. However their influence may extend beyond their family to wherever the cause of their death is. Maximally, such influences are predicated on vengeance. They may have felt 
offended or unjustly treated while they were alive or not properly buried when they died or accorded befitting burial, or for delay in second burial. They may feel offended for being unjustly killed by person(s). They may also be aggrieved when sacrifices are not made to establish or maintain ontological relationship to assert their relevance. Ancestors may also cause death; but their actions are not malevolent. Such actions are wrought to forestall calamities due to befall a people as a result of omission or misdeed which can generate ontological disharmony with the ancestors and which can inflict calamity on those under their protection.

God: God is believed to cause some deaths particularly those of the aged. When an old person dies the Esan people often say God has called him or her. In their language they say edolegbale. This means his or her days are completed. They also say okbian do hen-an or okbi uwa ofubhegbe. These translate respectively into he has gone home to rest or to house of peace. These suggest that this world is not a permanent home or that it is a place of turmoil. Although there is terrific fear of death, there seems to be an exemption of those who are very old, who probably have children that are also growing old. Since the prayer of every Esan person is that his or her children should not die before him or her, such old people would wish to die before their children begin to die of old age in their own eyes. They would also want to join the ancestors. Another reason is that if their children continue to die one after the other before them, not only that they will feel so bad about it, or that they will have no child(ren) to accord them befitting burial that would make them relevant in the ancestral realm, but they may be indicted of killing or using their children to elongate their life span. In this case the Esan will say oro omon du uhonmon.

This is why when such old people die it is often believed that their death is natural. Natural death is the only death caused and ordained by God; and it is the death of the aged. Such deaths are least grieved and well celebrated. Since they are natural, most cultures call it good death. In Esan, although they are believed to be natural, in the deeper yearnings of the people, they are caused by some agent(s) for a purpose; and the principal purpose is to prevent the aged from eating the fruits of their labour. Such opposing beliefs do not only defile, but also assault, obliterate and nullify the idea of a good death among Esan people. 


\section{Interrogating Esan Causal view on Death}

From the foregoing it is evident that these beliefs concerning the causes of death are not limited to Esan people; they are predominant in most other African cultures. The causes of death (Oboh, et.al. 1987: 14; Ali and Agogo, 2001: 107) among the Igede people of Benue state in Nigeria do not have significant difference with the Esan account. The near-replica in some beliefs in most African cultures does not pertain only to causes of death but also to other beliefs about death and some other African spheres of life.

Although death seems bad from the point of view of the Esan traditional conception of the causes of death, there are also some beliefs in Esan which are agreeable that death is good particularly for the aged as already mentioned. At such death, the Esan would say o khi uwa esili, that is, he has gone to a good home. The notions of okbian do hen-an and okbi uwa ofubhegbe already mentioned, and which respectively translates into "he has gone home to rest" and "he has gone to home of peace" depict good death. For those who suffer prolonged illness or excruciating pain without any hope of survival, the Esan would say awoyu wo me no nan. This means "to die is better than this". However, it may still be believed that such illness is caused. At the death of such persons, the Esan would say oyu si bhoya re, that is, "he died to leave suffering"; they would also say non do hen-an - "let him go and rest". In this case death is a respite.

Thoughts like these suggest that death is not necessarily conceived as evil in Esan. But one indisputable fact is that, with regard to the causes of death, which are essentially metaphysically explained in traditional Esan thought system, death (whatever the cause may be) is conceived as un-ideal, unwelcomed, harm, evil, pain, unwanted and mystery.

The account presented by Segun Gbadegesin on Yoruba people has some resemblances and differences with the Esan account. In some African societies, there is no desire to perpetuate all lives. According to Segun Gbadegesin, the perception of death cannot be separated from the value of a people. He writes that there is in Yoruba culture, the "concept of "ikuyajesin" - death is preferable to loss of dignity" (Gbadegesin, 2009: 31). This is why:

(a) A woman would refuse surgical operation for the treatment of her breast cancer because it would leave her without a breast.

(b) A man would commit suicide because an automobile accident left him paralyzed from the waist down. 
(c) The daughter of a 90-year-old woman would not give approval for a surgical operation to be performed on her mother because she was, in her view, old enough to die peacefully in her own home than to die in hospital or to live longer in crisis.

(d) The relatives of an aged dying woman, concerned about her incoherent utterances bordering on "confessions" about past "wickedness," would decide to kill her on their own (Gbadegesin. 2009: 31) to avert making indicting and defamatory confessions that can dent her image or those of her family or bring them to disrepute.

From the work of Segun Gbadegesin, it is clear that in Yoruba culture just as it may be in some other cultures, people may choose or be allowed to die or killed if their continued existence would lead to a loss of dignity. For example,

[t] he woman who refused a surgical operation to remove a cancerous breast is articulating the values of the community concerning death with dignity. And while it is difficult to see how the belief on the dignity of death relates to actualizing one's potential and participating in the community, the Yoruba do not see a conflict. Death is not the end of life; it is only a transition from one form of existence to another. The world of the dead is an extension of the world of the living and the dead commune with, and participate in the life of, the community of the living (Gbadegesin, 2009: 33). The view of Emmanuel Onyechere Anyim-Osigwe seems to corroborate the Esan view of death as something bad. In his reflection on life, its origin, purpose, end and how it is to be lived, Emmanuel Anyim-Osigwe observes some seeming contradictions and the puzzles of life. For him, the puzzles of death and the suffering of life makes death more provoking. Death appears to have provided an escape for man in the face of daunting challenges and difficulties of life. Despite this, death does not seem to be a better option. He write that "in the vagaries of life and the difficulties that it portends, the greater number of men would rather hold on to that life, afraid of the aftermath death, limited by the unknown, and trusting upon the hope that by perseverance the drudgery and dull moments of today would engender the shining light of tomorrow" (AnyiamOsigwe, 2013: xii).

There are dilemmas confronting the Esan attribution of metaphysical causes to death. It implies that one ought not to die or that death is always metaphysically caused and if not caused, it would not occur. It also implies that death is bad. But some of these beliefs they hold concerning the causes of death are 
counterfactual to nature and experience. Importantly, death is not all bad; rather, it seems to be good in some sense either for the deceased or the living. Despite the metaphysical conception which the Esan have concerning the causes of death, there are some moral relevance of death. We shall attend to this in some details.

\section{Some Moral Implications of Death in Esan}

This in a way serves as continuation of the critique of the Esan metaphysical causation of death even within the Esan belief system. The consciousness that death is inevitable, and that it is a debt which we must pay in turn without escape, enhances social order. Everybody in Esan society believes that they will die one day. They also believe in life after death. These have tremendous moral signification for Esan people. The realization of the existential fact that we will die one day makes people to be kind to others. It makes them to live sincerely and abide by the golden rule. Their indoctrinated beliefs that the evil that men do live after them, that ebunu lele imien obha noghu ubolo - whatever the mouth eats must without fail worry the anus, - and that a good name is better than riches make them shun vices. They therefore lead good lives so that:

1. Their good deeds and name will be echoed after their death.

2. They will live long.

3. They can join the ancestors.

4. They can leave good legacy.

5. They can attract befitting burial which is the prelude to joining the ancestors.

6. And very importantly, people will treat their children well when they are no longer alive.

Another way death inform moral behavior among Esan people is that the sight of a dying person bring them to the realization that they too will be in that situation one day. Their knowledge of the irremediable and irreplaceable loss of the dead makes them value life the more. These influence their moral attitude toward the sick, the suffering, the dying and the dead. It enhances their senses of solidarity toward others as co-potential victims of death.

An aspect of the work of Julius Ekoh explains some moral implications of death in Esan culture. According of Ekoh, part of the Esan belief which has some socio-behavioral cum moral implications is judgement after death. Esan 
people believe that there is reward for the good and punishment for the wicked. They believe that at death the soul of the deceased

leaves the body and proceeds on a journey to the world of the spirit to meet 'Osenobulua' the Supreme Being for judgement.... In their understanding of judgement, those who lead good and upright lives enter the ancestral world and join the ancestors to enjoy perfect union and rest. The wicked and those who lead evil lives according to Esan tradition are sentenced to a wretched, aimless, hopeless, restless and miserable existence in what is called in Esan tradition Agbin Ibianmbinvin, (Life of the shell of the kernel) (Ekoh, 2014, p. 205).

This depicts a life of torture, an unbearable life or a life of maximum discomfort in the hereafter. In order to escape this descriptive life of ordeal after death, the Esan people would choose to lead good life here even when sacrifices are involved in order to have a blissful life in the hereafter. In Esan traditional belief, the notorious evil doers who are known to have committed some serious crimes inescapably begins their punishment here on earth after death. "[T]hey are not given proper burial at death, they are not venerated or consulted or invoked at prayers for blessing and mediation" (Ekoh, 2014, pp. 205-206). They are thus not only consigned to spiritual and ancestral redundancy. By these, their being is diminuted and corrupted, their force quenched, and their wellbeing in the spirit world impaired.

This notion of reward and punishment greatly influence the life of Esan people. "For them hell begins on earth. They believe strongly that all that is done on earth shall be accounted for in this life and or in the hereafter. Their belief in judgement either in the earthly life or in life after death serves as a check to the perpetuation of evil and their perpetuator in the traditional Esan society and community" (Ekoh, 2014: 205-206). This implies that for Esan people, human beings are subject to judgement and its aftermath punishment and reward whether dead or alive. Thus, in Esan belief, reward and punishment in the hereafter help to maintain law and order in the present life since "one's moral rectitude or turpitude in his or her earthly life warrants or determines (italics mine) reward or punishment" (Ekoh, 2014: 206) after death. "While those who lived repugnant and evil life receive punishment for their wickedness and exclusion from the ancestral world, the virtuous on the other hand are rewarded with 
blessed life in the ancestral world, and are sometimes projected as moral models, heroes and intercessors for the living" (Ekoh, 2014, p. 206).

John Onimhawo, Matthew Izibili and Benson Igboin capture an aspect of the importance of death from Esan perspective. They attempt to provide answer to the fundamental questions concerning the importance which discussions about death have among the Esan people. They argue that

[t]he acceptance of death as an inevitable event in one's life has both moral and social importance to Esan people. First, its moral importance includes: showing the vanity of this world and what it has to offer. In this connection, it shows we came to this world empty handed and that we will go the same way after death. This, in a way, teaches the moral lesson against greed and covetousness. Another moral importance of death is that it brings to the awareness of every rational Esan person that he must be accountable for every action he takes either to God or to ancestors. In the light of this, Esan people are cautious not to incur the wrath of God or spirits of the ancestors (Onimhawo, Izibili and Igboin, 2006: 166).

Generally, death spurs people into pondering on the meaning of life.

\section{Conclusion}

Despite some problems that are inherent in the Esan traditional understanding of the causes of death, their beliefs in metaphysical causation and their awareness of the moral implications of death help to organize their individual and community lives meaningfully. But the contemporary norm now diverges significantly from the traditional norm about some of these beliefs. This has impaired their moral and social conceptions for the proper functioning of community life. In contemporary time, people's attitudes do not show that they will die. But this does not mean that they will not die. And this does not exempt them from moral and social responsibilities. What it means is that they are morally callous and insensitive, and are thus, not using their present to shape their future.

Nevertheless, the beliefs in these metaphysical causes have some negative implications that are antithetical to reality. Since any kind of death and at any age is always metaphysically caused, it implies that one ought not to die or de- 
ath would not occur if not for metaphysical causal agents. This suggests that life ought to continue ad infinitum save these metaphysical causal agents. This rules out of place natural deaths and thus conceives all deaths as bad. Such metaphysical beliefs can result in indictment, prosecution, punishment and killing of innocent people. They can also constitute sources of stigma on the innocent accused. In a positive sense, the significant deviation of contemporary norm from the traditional norm about some of these beliefs enables some people to accept death as natural phenomenon and avert the wrong notions attached to metaphysical causes.

Death has some relevance to the living as well as to the dead. It influences positively and concretely the people's behavior and way of life. The people adopt good living habit partly to avert the aftermath negative consequences of indecent living after death. In this sense, death enhances social order. It also removes the dead from the burden of life especially when life is no longer agreeable or worth living. Therefore a proper understanding of death would inform people's right attitude when death occurs. This would enable people to accept death as a natural phenomenon and erase suspicions and problems generated by metaphysical causal attributions. From this study, it is evident that although death seems bad from the Esan cultural view, there are also some beliefs in Esan which seems agreeable that death is good in some rare sense, particularly for the aged and the critically and hopelessly ill for whose sake death is seen as respite. But ultimately, death is conceived as un-ideal and unwanted. Despite the vicissitudes of life, life is preferable to death in Esan thought.

\begin{abstract}
This essay focuses on the analyses of the metaphysical causes of death in Esan culture and the implications and evaluations of the beliefs in such causes. It begins by expositing the Esan understanding of death and then discusses how death constitutes mystery for Esan people. It holds that in Esan the question of 'the why of death', philosophically speaking, does not admit any satisfactory answer. The study then makes in-depth analyses of the Esan conceptions of the metaphysical causes of death, - as wrought by witches, wizards, diabolic persons, evil consequences, devil, spirits, deities, malevolent beings and God, - the attitudes such beliefs generate and what they imply - that death is bad, one ought not to die and indictment of innocent people as causal agents whenever human death occurs. The study argues that although there is the conception of death as good only for the aged, underneath such belief is the explicit metaphysical conception of all deaths as caused and thus, bad. Contrary to the people's conception of death as bad, the study
\end{abstract}


argues that death has some relevance to the living and the dead as well as some practical and moral implications for the living. It argues that death influences the people's behavior and way of life concretely. In the course of inquiry, the study attempts simultaneously an excursion into comparative discourse with some other cultures.

Key words: death in Esan culture, mystery of death, metaphysical causal agents, death as bad, relevance of death

\section{Bibliography}

Acemoglu, Daron and Robinson, James. (2013). Why Nations Fail: The Origins of Power, Prosperity and Poverty. London: Profile Books Ltd.

Ali, A. and Agogo, Peter. (2001): Traditional African Beliefs: The Case of Igede People of Benue State, Nigeria. A.O. Orubu. Ed. African Traditional Religion. Benin City: Institute of Education, University of Benin. 104-115.

Alli, Peter. (2011). Esan Cosmology and its Effects on the Social Behaviour of the People: Bringing all Things under Christ. Lagos: Deocraft Communications.

Anyiam-Osigwe, Michael. (2013). Foreword: Knowledge as the Premise of Meaningful Existence: Anyiam-Osigwe's Treatises on the Holistic Approach to Human Existence and Development. Owolabi, K.A. and Ekanola, A.B. Eds. A Holistic Approach to Human Existence and Development. Ibadan: Hope Publications. xii-xviii.

Basden, G.T. Niger Ibos. Quoted in Olumide Lucas. (1970). Religions in West Africa and Ancient Egypt. Printed by the Nigerian National Press, Apapa Lagos.

Boethius, Anicius Severinus. (1969). The Consolation of Philosophy. V.E. Watts. Tran. and Intro. London: Penguin Books.

Ekoh, Julius Ehikioya. (2014). Life, Death and Life after Death: An Esan-Chriastian Response. Benin City: Floreat Systems.

End of Life Care: An Ethical Overview. Center for Bioethics. University of Minnesota. 2005.

Fairbanks, Rick and Taliaferro, Charles. (2006). Death [Addendum]. Donald M. Borchert. Ed. Encyclopedia of Philosophy. Vol. 1. 2Ed. Farmington Hills: Thomson Gale. 653-654.

Gbadegesin, Segun. (2009). Culture and Bioethics. Helga Kuhse and Peter Singer. Eds. A Companion to Bioethics. 2Ed. Oxford: Wiley-Blackwell. 24-35.

Lucas, Olumide. (1970). Religions in West Africa and Ancient Egypt. Printed by the Nigerian National Press, Apapa Lagos.

Oboh, S.O. Et.al. (1987). Igede Gedegede: Selected Essays on Igede Cultures and Language. Makurdi: Onaivi Ent. Ltd. Cited in A. Ali and Peter O. Agogo, (2001). Traditional African Beliefs: The Case of Igede People of Benue State, Nigeria. A.O. Orubu Ed. African Traditional Religion. Benin City: Institute of Education, University of Benin. 104-115.

Okojie, Christopher. (1994). Esan Traditional Laws and Custom with Ethnographic Studies of the Esan People. 2Ed. Benin City: Ilupeji Press Ltd.

Olson, Robert G. (2006). Death. Donald M. Borchert. Ed. Encyclopedia of Philosophy. Vol.1. 2Ed. Farmington Hills: Thomson Gale. 650-653. 
Onimhawo, John, Izibili, Matthew and Igboin, Benson. (2006). Theistic, Atheistic Arguments: Issues and Problems. Accra: Deocraftghana.

Orubu, A.O. (2001). The Hereafter in African Traditional Religion. A.O. Orubu. Ed. African Traditional Religion. Benin City: Institute of Education, University of Benin. 153-166.

Osae, T.A. and Odunsi, A.T.O. (1973). A Short History of West Africa: A. D. 1800 to the Present Day. Vol. 2. London: University of London Press Ltd.

Webster, J.B. and Boahen, A.A. with Idowu, H.O. (1967). The Growth of African Civilization: The Revolutionary Years: West Africa since 1800. London: Longmans Groups Ltd.

World Health Organization. Injury: A Leading Cause of the Global Burden of Disease. Krug E. Ed. Online at http://whqlibdoc.who.int/hq/1999/WHO_HSC_PVI_99.11.pdf. Accessed $3 / 1 / 04$.

Felix Ayemere Airoboman - B.A. (Philosophy) University Of Benin, Benin City, Nigeria, M.A. (Philosophy) University Of Ibadan, Ibadan, Nigeria

Ph.D (Philosophy) University Of Ibadan, Lecturer 1 Department Of Philosophy, Faculty Of Arts, University Of Benin, Benin City, Nigeria 